\title{
複数対象物に対するパワーグラスプの最適化*
}

\author{
吉川恒夫*1, 渡辺哲 陽*2, 大東睦 夫*3
}

\section{Optimization of Power Grasps for Multiple Objects}

\author{
Tsuneo YOSHIKAWA*4, Tetsuyou WATANABE and Mutsuo DAITO \\ ${ }^{* 4}$ Department of Mechanical Engineering, Graduated School of Engineering, Kyoto University, \\ Yoshidahon-machi, Sakyo-ku, Kyoto-shi, Kyoto, 606-8501 Japan
}

\begin{abstract}
Power grasp is a grasp that can hold objects stably without changing the joint torques of fingers. Almost all studies on power grasp deal with one object. But it is more efficient to hold and manipulate multiple objects at the same time. This paper derives a condition for power grasp for multiple objects. In this procedure, we discuss the set of the external force that can be resisted by only the constraints between objects. From the discussion, we derive the set of the external force that should really be resisted. We also define an optimal power grasp from the viewpoint of decreasing the work of joint torques, and derive the procedure. Lastly, we show some numerical examples to verify the validity of our approach.
\end{abstract}

Key Words: Robot, Dynamics of. Machinery, Friction, Power Grasp, Optimization, Multiple Objects

1.はじめに

テーブルの上に置いてある，比較的小さな軽い䘽数 の対象物を他のテーブルへと移すというタスクが与え られた場合，人は持てる数だけ対像物を持って運ぶと いった操作をする．これは一つずつ対象物を移すより も効薪が良いためと考えられる.ロボットハンドの操 作に関しても京様のことが言える.このことから，近 年多指ハンドを用いた複数の対像物の把持と操りに関 する研究が行われつつある. Aiyama ら(1)は，双腕に よって複数刘象物を挟みつけて持ち上げる操作を提案 した．余ら (2)は，接触部における摩摖条件を考慮して 複数対象物を安定把持するための把持内力に関する解 析を行った. 原田ら ${ }^{(3)(4)}$ は，転がり接触を前提とした 複数対象物の包み込み把握と対象物のすくい上げや, 重力場における複数対象物の平行把持とそのロバスト 性に関する研究を行った。

しかしながら、これら複数刘象物の把持という矿究 はまだ始まったところであり，多くの課題が残されて いる. その一つがパワーグラスプに関する䂤究である. パワーグラスプとは，あらかじめ各関節に適当なトル クを与えておけば，把持している対象物に任意方问の 外力が働いたとき，関節トルクを変えなくても機棈的 に接触力を発生し，外力を打ち消すことができるとい う把持である. 単一対象物に対するパワーグラスプに

* 原稿受付 2001 年 9 月 10 日.

*2 正員, 京都大学大学院工学研究科(画606-8501 京都市左京 区吉田本町).

*2 正旦. 京都大学大学院.

*3 京都大学大学院.

E-mail : t60x0113@ip.media.kyoto-u.ac.jp
関しては様々な咞究が行われている，小俣ら ${ }^{(5)}$ は，对 象物と指リンクの運動に関する拘束からパワーグラス プであるための条件を尊出し，すべり方向の制限と摩 摖の条件から発生可能な把持力には制限があることを 示した. 張ら ${ }^{(6)}$ は，摩擦力はすべりの速度の反対方向 に発生するという性啠を利用して各関節がすべりを生 じる僢間の接触力を計算し, 対像物を動かすのに必要 な外力を求めた. 余ら ${ }^{(7)}$ は, パワーグラスプの必要十 分条件を導出し，把持する対象物が与えられたときの 最適なパワーグラスプを定莪した. しかしながら，複 数対象物に対するパワーグラスプの研究は見あたら ない.

本諭文では，多自由度を持つ複数本の指で複数対象 物を包み込み把握する場合に対し，パワーグラスプの 成立条件と最適化について考察を行う。本論文の構成 は以下の通りである．まず，第 2 章で複数の対象物を 把持したときにパワーグラスプを実現するための条件 を墕出する. 次に，第 3 章で把持する複数の対象物が 与えられたときの最適なパワーグラスプを定義し，そ の決定法を示す. 最後に，第 4 章で数值例を示し，そ の有効性を検証する.

\section{2. パワーグラスプの成立条件}

本章では，複数の対象物が与えられたときどのよう な把持がパワーグラスプとなるのかについて述べる. まず，指の関節速度と対象物の速度の間の運動学的関 係式を迸出し，これをもとに関節トルク，接触力，対 


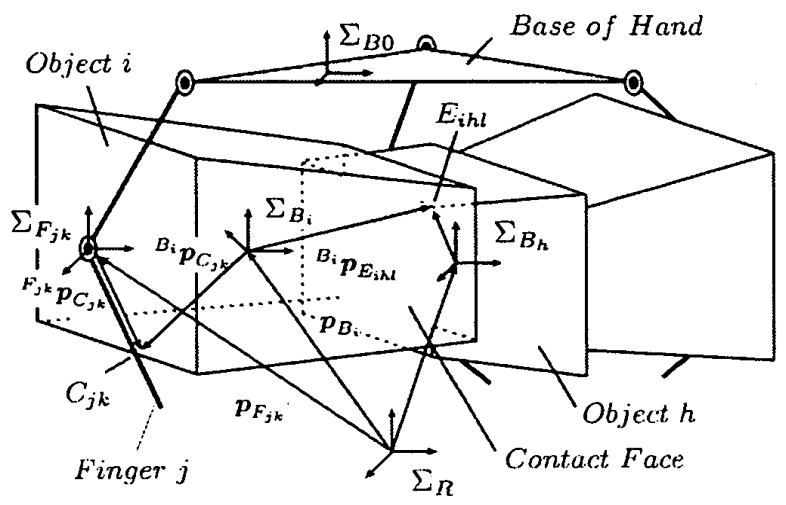

Fig. 1 Robot hand and objects

象物に加わる並進及び回転の外力の間の関係式を導く． 次に接触力の摩擦条件を提示する.ささらに, パワーグ ラスプを構成する場合に抗しなければならない外力の 集合について考察する. 最後にパワーグラスプを実現 するための条件を示す. 以下では, 三次元空間内の運 動について議論するが, 得られた結果は当然のことな がら若干の修正を加えることにより二次元平面内の運 動に対しても適用できる.

2.1 対象とする系 本研究では $N(\geq 1)$ 本の指 で $M(\geq 1)$ 個の対象物を把持する場合を考える（図 1 参照).この系において次の仮定を置く.

・各対象物は凸多面体である.

・指のリンク（または指先）は対象物の稜線（また は平面）と摩擦あり点接触をする.

- 対象物間の接触面（ハンドのベースと対象物と の接触を含む) は摩擦あり面 (点, 線) 接触とす る. また, 面 (線) 接触は複数個の点接触で近似 できる.

- 各指の各リンクには最高でも一つの接触点しか存 在しない.

また，基準座標系を $\Sigma_{R}$, 対象物 $i(=1,2, \ldots, M)$ に固 定された座標系を $\Sigma_{B_{i}}$, ベースに固定された座標系を $\Sigma_{B_{0}}$, 指 $j(=1,2, \ldots, N)$ の第 $k\left(=1,2, \ldots, L_{j}\right)$ リンク $F_{j k}$ に固定された座標系を $\Sigma_{F_{j k}}$ とおく（ $L_{j}$ は指 $j$ の関 節数.ただし，ある関節から先のリンクに接触点を持 たない場合, その関節は数に含めない.).

2.2 運動学 本節では指の関節速度と対象物の 速度の間の運動学的関係について考察する.

基準座標系 $\Sigma_{R}$ から見た $\Sigma_{A}$ の位置べクトルを $p_{A}$, 姿勢を表す回転行列を $\boldsymbol{R}_{A}$ とする. また，指 $j$ の $k$ 番 目の接触点 $C_{j k}$ の位置を ${ }^{A} p_{C_{j k}}$, 対象物 $i$ と対象物 $h$ の 接触面の $l\left(=1,2, \ldots, T_{i h}\right)$ 番目の端点の位置を ${ }^{A} p_{E_{i h l}}$ とする（ $T_{i h}$ は対象物 $i$ と対象物 $h$ との接触面におけ
る端点の総数を表す).

このとき, 対象物とリンクとの間または対象物と対 象物との間に滑り及び分離が生じなければ以下の式が 成り立つ ${ }^{(3)(4)(8)}$.

$$
\begin{aligned}
\boldsymbol{D}_{B_{i j k}}\left[\begin{array}{c}
\dot{\boldsymbol{p}}_{B_{i}} \\
\boldsymbol{\omega}_{B_{i}}
\end{array}\right] & =\boldsymbol{D}_{F_{j k}}\left[\begin{array}{c}
\dot{\boldsymbol{p}}_{F_{j k}} \\
\boldsymbol{\omega}_{F_{j k}}
\end{array}\right] \\
\boldsymbol{D}_{E_{i n l}}\left[\begin{array}{c}
\dot{\boldsymbol{p}}_{B_{i}} \\
\boldsymbol{\omega}_{B_{i}}
\end{array}\right] & =\boldsymbol{D}_{E_{h i l}}\left[\begin{array}{c}
\dot{\boldsymbol{p}}_{B_{h}} \\
\omega_{B_{h}}
\end{array}\right]
\end{aligned}
$$

ただし，

$$
\begin{aligned}
& D_{B_{i j k}}=\left[\begin{array}{ll}
\boldsymbol{I}_{3} & -\left[\left(\boldsymbol{R}_{B_{i}}{ }^{B_{i}} \boldsymbol{p}_{C_{j k}}\right) \times\right]
\end{array}\right] \in \mathcal{R}^{3 \times 6}
\end{aligned}
$$

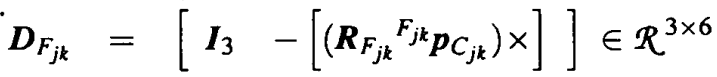

$$
\begin{aligned}
& \boldsymbol{D}_{E_{i h l}}=\left[\begin{array}{ll}
\boldsymbol{I}_{3} & -\left[\left(\boldsymbol{R}_{B_{i}}{ }^{B_{i}} \boldsymbol{p}_{E_{i h l}}\right) \times\right]
\end{array}\right] \in \boldsymbol{R}^{3 \times 6}
\end{aligned}
$$

である.ここで, $[a \times]$ は外積演算と等価な行列であ り， $I_{i}$ は $i$ 次元単位行列である. また, $\omega_{B_{i}}$ は対象物 $i$ の回転角速度, $\omega_{F_{j k}}$ は指のリンク $F_{j k}$ の回転角速度で ある. なお, 式 (1) は $\Sigma_{F_{j k}}$ の速度と $\Sigma_{B_{i}}$ の速度が接触 点 $C_{j k}$ において一致するという関係を表し，式(2)は $\Sigma_{B_{i}}$ の速度と $\Sigma_{B_{h}}$ の速度が対象物 $i$ と対象物 $h$ の間の 接触面の $l$ 番目の端点において一致するという関係を 表したものである.

指 $j$ の関節変数を $q_{j} \in R^{L_{j}}$ とすると, 座標系 $\Sigma_{F_{j k}}$ の速度の関係は,

$$
\left[\begin{array}{c}
\dot{p}_{F_{j k}} \\
\boldsymbol{\omega}_{F_{j k}}
\end{array}\right]=J_{F_{j k}} \dot{\boldsymbol{q}}_{j}
$$

で与えられる. ただし， $J_{F_{j k}} \in R^{6 \times L_{j}}$ はヤコビ行列で ある. 式(1)(3)より, 指 $j$ の関節速度と各対象物の速 度との関係は次のようになる。

$$
\boldsymbol{D}_{B_{j}}\left[\begin{array}{lllll}
\dot{\boldsymbol{p}}_{B_{1}}^{T} & \boldsymbol{\omega}_{B_{1}}^{T} & \cdots & \dot{\boldsymbol{p}}_{B_{M}}^{T} & \boldsymbol{\omega}_{B_{M}}^{T}
\end{array}\right]^{T}=J_{C F_{j}} \dot{\boldsymbol{q}}_{j}
$$

ただし，

$$
\begin{aligned}
\boldsymbol{J}_{C F_{j}}= & {\left[\begin{array}{c}
\boldsymbol{D}_{F_{j 1}} \boldsymbol{J}_{F_{j 1}} \\
\vdots \\
\boldsymbol{D}_{F_{j K_{j}}} \boldsymbol{J}_{F_{j K_{j}}}
\end{array}\right] \in \mathbb{R}^{3 K_{j} \times L_{j}} } \\
\boldsymbol{D}_{B_{j}}= & (\mathrm{k})\left[\begin{array}{ccc}
(i) & \\
\cdots & \vdots & \cdots \\
\boldsymbol{O} & \boldsymbol{D}_{B_{i j k}} & \boldsymbol{O} \\
\cdots & \vdots & \cdots
\end{array}\right] \in \mathbb{R}^{3 K_{j} \times 6 M}
\end{aligned}
$$

である.ここで， $D_{B_{j}}$ は，それを構成する $K_{j} \times M$ 個 のブロックのうち, その第 $(k, i)$ ブロックが $D_{B_{i j k}}$ でそ れ以外が $O$ となるる行列である. また, $K_{j}$ は指 $j$ の 接触点数を表している. 
次に対象物 $i$ と対象物 $h(>i)$ とが接触していると き, 式(2)より,

$$
\boldsymbol{D}_{E_{i}}\left[\begin{array}{lllll}
\dot{p}_{B_{1}}^{T} & \omega_{B_{1}}^{T} & \cdots & \dot{p}_{B_{M}}^{T} & \omega_{B_{M}}^{T}
\end{array}\right]^{T}=0
$$

が得られる.ただし,

(i)

(h)

$$
\boldsymbol{D}_{E_{i}}=(1)\left[\begin{array}{ccccc}
\ldots & \vdots & \ldots & \vdots & \ldots \\
\boldsymbol{O} & \boldsymbol{D}_{E_{i h l}} & \boldsymbol{O} & -\boldsymbol{D}_{E_{\text {hil }}} & \boldsymbol{O} \\
\ldots & \vdots & \ldots & \vdots & \ldots
\end{array}\right] \in \mathbb{R}^{3 T_{i h} \times 6 M}
$$

である. $D_{E_{i}}$ は，それを構成する $T_{i h} \times M$ 個のブロック のうち, 第 $(l, i)$ ブロックが $D_{E_{i h l}}$, 第 $(l, h)$ ブロックが $-D_{E_{\text {hil }}}$, それ以外が $O$ となる行列である. なお, 対 象物 $i$ がベースの場合には $D_{E_{i h l}}=0$ となる.

式 (4),(5)より, 指の関節速度と複数対象物の速度と の関係は次のようになる.

$$
\boldsymbol{A}\left[\begin{array}{c}
\dot{\boldsymbol{x}} \\
-\dot{\boldsymbol{q}}
\end{array}\right]=\mathbf{0}
$$

ただし，

$$
\begin{aligned}
& \dot{\boldsymbol{x}}=\left[\begin{array}{lllll}
\dot{\boldsymbol{p}}_{B_{1}}^{T} & \boldsymbol{\omega}_{B_{1}}^{T} & \cdots & \dot{\boldsymbol{p}}_{B_{M}}^{T} & \boldsymbol{\omega}_{B_{M}}^{T}
\end{array}\right]^{T} \in \mathcal{R}^{6 M} \\
& \dot{\boldsymbol{q}}=\left[\begin{array}{lll}
\dot{\boldsymbol{q}}_{1}^{T} & \cdots & \dot{\boldsymbol{q}}_{N}^{T}
\end{array}\right]^{T} \in \mathcal{R}^{L} \\
& \boldsymbol{A}=\left[\begin{array}{ll}
\boldsymbol{D} & \boldsymbol{J}
\end{array}\right] \in \mathbb{R}^{3(K+T) \times(6 M+L)} \\
& \boldsymbol{D}=\left[\begin{array}{lllll}
\boldsymbol{D}_{B_{1}}^{T} & \cdots & \boldsymbol{D}_{B_{N}}^{T} & \left(\boldsymbol{D}_{E_{0}}\right)^{T} & \boldsymbol{D}_{E_{1}}^{T}
\end{array}\right. \\
& \left.\cdots \quad D_{E_{M-1}}^{T}\right]^{T} \in \mathcal{R}^{3(K+T) \times 6 M} \\
& J=\left[\begin{array}{ccc}
J_{C F_{1}} & \cdots & 0 \\
\vdots & \ddots & \vdots \\
0 & \cdots & J_{C F_{N}} \\
(0 & \cdots & 0) \\
0 & \cdots & 0
\end{array}\right] \in R^{3(K+T) \times L}
\end{aligned}
$$

である. ただし, ベースと接触していないときには, ブ ロック行列中の（）内の成分は除く.また, $K=\Sigma_{i=1}^{N} K_{i}$, $T=\Sigma_{i, i<h} T_{i h}, L=\Sigma_{i=1}^{N} L_{i}$ である.

2.3 接触力 本節では指と刘象物との間にはた らく接触力, 対象物間の接触面の端点にはたらく接触 力, 及び関節トルクの間の関係について考察する. た だし, 対象物間の接触面にはたらく接触力は, その接 触面の端点における接触力の線形和で棐せると仮定 する.

接触点 $C_{j k}$ における指リンク $F_{j k}$ から対象物に加え られる接触力を $f_{C_{j k}} \in R^{3}$ とし, 対象物 $i$ と対象物 $h$ $(>i)$ との接触面の端点 $E_{i h l}$ において対象物 $h$ が対象 物 $i$ に対して加える接触力を $f_{E_{i h l}}$ とする. また，指 $j$
の関節トルクベクトルを $\tau_{j} \in R^{L_{j}}, \Sigma_{B i}$ 原点に働く並 進および回転の外力を $t_{i} \in R^{6}$ とすると, 式 (6) と仮 想仕事の原理より,

$$
A^{T} f=\left[\begin{array}{c}
D^{T} \\
J^{T}
\end{array}\right] f=\left[\begin{array}{c}
-t_{e} \\
\tau
\end{array}\right]
$$

を得る.ただし，

$$
\begin{aligned}
& f=\left[\begin{array}{ll}
f_{C}^{T} & f_{E}^{T}
\end{array}\right]^{T} \in \mathcal{R}^{3(K+T)} \\
& f_{C}=\left[\begin{array}{lll}
f_{C_{11}}^{T} & \cdots & f_{C_{N K_{N}}}^{T}
\end{array}\right]^{T} \in \mathcal{R}^{3 K} \\
& f_{E}=\left[\begin{array}{lll}
\left(f_{E_{021}}^{T}\right. & \cdots & f_{E_{0 h} T_{0 h}}^{T}
\end{array}\right) \\
& \left.\begin{array}{lll}
f_{E_{121}}^{T} & \cdots & f_{E_{M-1 M T_{M-1 M}}^{T}}
\end{array}\right]^{T} \in \mathcal{R}^{3 T} \\
& \boldsymbol{t}_{\boldsymbol{e}}=\left[\begin{array}{lll}
\boldsymbol{t}_{1}^{T} & \cdots & \boldsymbol{t}_{M}^{T}
\end{array}\right]^{T} \in \mathcal{R}^{6 M} \\
& \tau=\left[\begin{array}{lll}
\tau_{1}^{T} & \cdots & \tau_{N}^{T}
\end{array}\right]^{T} \in \mathcal{R}^{L}
\end{aligned}
$$

である. 式 (7)より各関節にあらかじめ一定のトルク $\tau_{C}$ を与えた場合，接触力の候補となり得るもの（候 補接触力） $f$ は以下のように裴すことができる.

$$
f=\left(J^{+}\right)^{T} \tau_{C}+\left(I_{3(K+T)}-J J^{+}\right) k_{1}
$$

ここで, $J^{+} \in R^{L \times 3(K+T)}$ は $J$ の疑似逆行列を表し $k_{1}$ $\in R^{3(K+T)}$ は任意べクトルを装している.この式の右 辺の第 2 項は，関節トルクに影幚を及ぼさない各指り ンク間の内力の集合を表している. 式 (8) を満たす候 補接触力の集合は,

$$
\begin{array}{r}
\mathcal{F}_{J}=\left\{f \mid f=\left(J^{+}\right)^{T} \hat{\tau}_{C} k_{c}+\left(I_{3(K+T)}-J J^{+}\right) k_{1},\right. \\
\left.k_{c}>0, k_{1} \in \mathcal{R}^{3(K+T)}\right\}
\end{array}
$$

と裴すことができる. ここで $\hat{\tau}_{C}\left(=\tau_{C} /\left\|\tau_{C}\right\|\right)$ と $k_{C}(=$ $\left.\left\|\tau_{C}\right\|>0\right)$ は $\tau_{C}$ の方向とその大きさを表している.

また, 式 (7) を $f$ に関して解くと

$$
f=\left(A^{T}\right)^{+}\left[\begin{array}{c}
-t_{e} \\
\dot{\tau}
\end{array}\right]+\left(I_{3(K+T)}-A A^{+}\right) k_{2}
$$

を得る.ここで, $\left(A^{T}\right)^{+}$は $A^{T}$ の疑似逆行列を表し， $k_{2} \in \mathcal{R}^{3(K+T)}$ は任意べクトルを装している. 式(10) より, もし $\operatorname{rank} A<(6 M+L)$ であれば, $\tau$ に対して一 定のトルク $\tau_{C}$ をあらかじめ与え, ある外力 $t_{e}$ が各対 象物に対して加わったとしても，その外力とバランス するような接触力が定まらない場合が存在する．この ことはその把持形態がパワーグラスプを權成すること ができないことを意味している.

2.4 摩擦条件本節では，指リンクと対象物の 接触点及び対象物と対象物との間の接触面での摩摖条 
件について考察する．なお，対象物間の接触面におい て，各端点における摩摖条件が満たされれば，その接 触面における摩摖条件は満たされるものとする。

指リンクと対象物との間にはたらく接触力 $f_{C_{j k}}$ と対 象物間にはたらく接触力 $f_{E_{i h l}}$ はそれぞれ接触点 $C_{j k}$, 端点 $E_{i h l}$ において次の静止摩摖条件を満たさなければ ならない。

$$
\boldsymbol{n}_{F}^{T} f_{F} \geq \frac{1}{\sqrt{1+\mu_{F}^{2}}}\left\|f_{F}\right\| \quad\left(F=C_{j k}, E_{i h l}\right)
$$

ここで, $n_{C_{j k}}, n_{E_{i h l}}$ はそれぞれ接触点 $C_{j k}, E_{i h l}$ におけ る対象物 $\left(\boldsymbol{n}_{E_{i h t}}\right.$ の場合は対象物 $\left.i\right)$ 内向き接触法線べ クトルであり, $\mu_{C_{j k}}, \mu_{E_{i h l}}$ はそれぞれ接触点 $C_{j k}, E_{i h l}$ における最大静止摩摖係数である.すずての接触点に 対して式 (11) を満たす $\boldsymbol{f}_{C_{j k}}, \boldsymbol{f}_{E_{i h l}}$ からなる集合は,

$$
\mathcal{F}_{F}=\left\{f \mid N^{T} f \geq \hat{\mu} \bar{f}\right\}
$$

と表される.ただし，

$$
\begin{aligned}
& \bar{f}=\left[\begin{array}{lll}
\left\|f_{C_{11}}\right\| & \cdots & \left\|f_{C_{N K_{N}}}\right\|
\end{array}\right. \\
& \left(\begin{array}{lll}
\left\|f_{E_{011}}\right\| & \cdots & \left\|f_{E_{0 M T_{0 M}}}\right\|
\end{array}\right) \\
& \left.\left\|f_{E_{121}}\right\| \quad \cdots \quad\left\|f_{E_{M-1 M T_{M-1 M}}}\right\|\right]^{T} \in \mathcal{R}^{(K+T)} \\
& \boldsymbol{N}=\operatorname{diag}\left[\begin{array}{llllll}
\boldsymbol{n}_{C_{11}} & \cdots & \boldsymbol{n}_{C_{N K_{N}}} & \left(\boldsymbol{n}_{E_{011}}\right. & \cdots & \boldsymbol{n}_{E_{0 h T_{0 h}}}
\end{array}\right) \\
& \left.\boldsymbol{n}_{E_{121}} \cdots \boldsymbol{n}_{E_{M-1 M T_{M-1 M}}}\right] \in \mathcal{R}^{3(K+T) \times(K+T)} \\
& \hat{\boldsymbol{\mu}}=\operatorname{diag}\left[\begin{array}{lll}
\left(1+\mu_{C_{11}}^{2}\right)^{-\frac{1}{2}} & \cdots & \left(1+\mu_{C_{N K_{N}}}^{2}\right)^{-\frac{1}{2}}
\end{array}\right.
\end{aligned}
$$

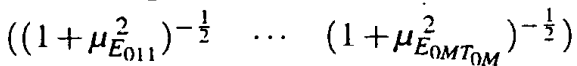

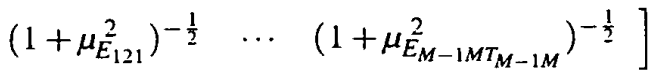

$$
\begin{aligned}
& \in \mathcal{R}^{(K+T) \times(K+T)}
\end{aligned}
$$

であり, diagはブロック対角行列を表すものとする.

2.5 抗しなければならない外力の集合複数対 象物をパワーグラスプする場合，単一対象物を把持す るときとは違い，対象物間の拘束のみによって抗する ことができる外力が存在する. それは, 対象物間の接 触面（線）の法線方向において互いに同じ大きさの力 で押しつけ合う力である．これに対応する外力を含ま ない全ての外力に抗することができれば，各対象物に はたらく任意の方向の外力に抗することができる. 本 節ではこのことについて考慮する.

対象物 $i$ と対象物 $h(i<h)$ の間の接触面の $l$ 番目の 端点の微小变位を $\Delta \boldsymbol{p}_{E_{i h l}}$ とおくと, 接触という拘束か ら，この微小変位のとり得る範因は式 (2)より

$$
\boldsymbol{n}_{E_{i h}}^{T} \Delta \boldsymbol{p}_{E_{i h l}}=\boldsymbol{n}_{E_{i n h}}^{T}\left(D_{E_{i h l}} \Delta \boldsymbol{x}_{i}-D_{E_{h i l}} \Delta x_{h}\right) \geq 0
$$

と表される.ただし， $\Delta x_{i}$ は対象物 $i$ の並進及び回転 方向の微小変位を表すものとする．これを全接触面の 全端点に関してまとめると

$$
N_{E}^{T} \Delta p_{E}=N_{E}^{T} D_{E} \Delta x \geq 0
$$

を得る.ただし

$$
\begin{aligned}
& \Delta \boldsymbol{p}_{E}=\left[\left(\Delta \boldsymbol{p}_{E_{021}}^{T} \cdots \Delta \boldsymbol{p}_{E_{0 h T_{0 h}}^{T}}\right)\right. \\
& \left.\Delta \boldsymbol{p}_{E_{121}}^{T} \cdots \Delta \boldsymbol{p}_{E_{M-1 M T M-1 M}}^{T}\right]^{T} \in R^{3 T} \\
& \Delta x=\left[\Delta x_{1}^{T} \cdots \Delta x_{M}^{T}\right]^{T} \in \mathcal{R}^{6 M} \\
& N_{E}=\operatorname{diag}\left[\left(\boldsymbol{n}_{E_{011}} \cdots \boldsymbol{n}_{E_{0 / T_{0 h}}}\right)\right. \\
& \left.\boldsymbol{n}_{E_{121}} \cdots \boldsymbol{n}_{E_{M-1 M T} T_{M-1 M}}\right] \in R^{3 T \times T} \\
& D_{E}=\left[\begin{array}{lll}
\left(D_{E_{0}}\right)^{T} & D_{E_{1}}^{T} \cdots & D_{E_{M-1}}^{T}
\end{array}\right]^{T} \in \mathcal{R}^{3 T \times 6 M}
\end{aligned}
$$

である.

これをもとに以下の命題が成り立つ.

命題 不等式

$$
\mathcal{T}_{E}=\left\{\boldsymbol{t}_{\boldsymbol{e}} \mid \boldsymbol{N}_{E}^{T} D_{E} \boldsymbol{t}_{\boldsymbol{e}} \geq \mathbf{0}\right\}
$$

を満たす全ての外力 $\tau_{e}$ に抗することができるなら，各 対象物にはたらく任意の方向の外力に対して抗するこ とができる.

<証明 > 文献 ${ }^{(9)}$ より以下の補題を得ることができる. 補題 各関節に一定のトルク $\tau_{C}$ を与えることで 複数刘象物を把持し静止させているとき, 複数対象物 に外力 $t_{e}$ がはたらき, それに応じて微小変位 $\Delta x$ 及び $\Delta q$ が生じたものとする. このとき系にはたらく仕事

$$
W=t_{e}^{T} \Delta x+\tau_{C}^{T} \Delta q
$$

が $W \leq 0$ を満たせばどの対象物もどの指も動かない.

さて, 式 (15) で表される外力集合は凹多面錘であ り,この集合に対する極鍾

$$
\mathcal{V}=\left\{z \mid y^{T} z \leq 0, \forall y \in \mathcal{T}_{E}\right\}
$$

が定義できる ${ }^{(10)}$. Farkas の定理 ${ }^{(10)}$ を用いると $\nu は$

$$
\mathcal{V}=\left\{t_{e} \mid t_{e}=-D_{E}^{T} N_{E} k_{3}, k_{3} \geq 0\right\}
$$

とも表せる．この表現より，極錘 $\nu$ に属する外力とは， 対象物間の接触面（線）の法線方向において互いに同 じ大きさの力で押しつけ合う力であることがわかる.

任意方向の全ての外力からなる外力空間 $R^{6 M}$ は, 式 (15) の凸多面鉏と式 (18) の極錘とで直和分解される (10). よって補題及び式 (16) より, 式 (15) に属する全 ての外力に対して抗することができる場合，Vに属す 
るどの外力による仕事も負または 0 であれば，任意の 方向の外力に対して抗することができる．Vに属す る外力に対応する接触力は, 外力がはたらかないとき の接触力を $f_{C}=f_{C i n i}, f_{E}=f_{E i n i}$ とすると, 式(18)よ り $f_{C}=f_{C i n i}, f_{E}=f_{E i n i}-N_{E} k_{3}\left(k_{3} \geq 0\right)$ と表すことがで きる.このことから，関節トルクには関わらない，ま た接触面での摩擦条件によらない力であることがわか る.さらに，Vに属する外力がはたらいた場合の関節 の微小変位 $\Delta \boldsymbol{q}$ は，外力がはたらかない場合の微小変 位 $\Delta q_{\text {ini }}$ と一致すると言える．外力がはたらかない場 合，すなわち外力 0 がはたらく場合とは，複数対象物 を把持し静止させている状態ゆえ，このとき系にはた $5<$ 仕事は

$$
W=\tau_{C}^{T} \Delta q_{i n i} \leq 0
$$

と表す事ができる．以上から，Vに属する外力による 仕事は, 式(13)(19)より

$$
\begin{gathered}
W=\boldsymbol{t}_{e}^{T} \Delta x+\tau_{C}^{T} \Delta q=-k_{3}^{T} N_{E}^{T} D_{E} x+\tau_{C}^{T} \Delta q_{i n i} \\
=-k_{3}^{T} N_{E}^{T} p_{E}+\tau_{C}^{T} \Delta q_{i n i} \leq 0
\end{gathered}
$$

となる. よって，上の命題が成り立つことがわかる.

2.6 パワーグラスプとなるための条件 今まで の議論をもとに本節では複数対象物を把持した場合, それがパワーグラスプとなるための条件を導出する.

複数対象物を把持するためには，接触力を発生する ことができ，かつその接触力が接触点（線，面）での 摩擦条件を満たさなければならない。ゆえに，実際に 発生できる接触力の集合は式 (9)(12) より,

$$
\mathcal{F}=\mathcal{F}_{\mathcal{J}} \cap \mathcal{F}_{\boldsymbol{F}}
$$

と表すことができる. 式(9)において ${ }_{C}$ を一定にし， $k_{C} ， k_{1}$ を変化させると考えると, $\mathcal{F}_{J}$ は凸錘となる. ま た， $\mathcal{F}_{F}$ も凸錘であるため ${ }^{(7)}$,式(21)より $\mathcal{F}$ も凸鏵と なる. 式(21)を満たす $f$ を式 (7)に代入することで得 られる $t_{e}$ は $\tau_{C}$ の方向 $\boldsymbol{\tau}_{C}$ を変化させることなく抗す ることのできる外力である. この抵抗可能な外力 $t_{e}$ す べてからなる力集合は,

$$
\mathcal{W}=\left\{t_{e} \mid t_{e}=-D^{T} f, f \in \mathcal{F}\right\}
$$

と表すことができ， $W$ も凸鍾となる．

ゆえに，2.3 節での $\boldsymbol{A}$ の rank に関する考察及び 2.5 節の命題を考慮すれば，ある把持に対して適当な関 節トルクの方向 ${ }_{C}$ が与えられた場合, その把持がパ ワーグラスプを構成するための条件は以下の 2 条件が 成立することである.

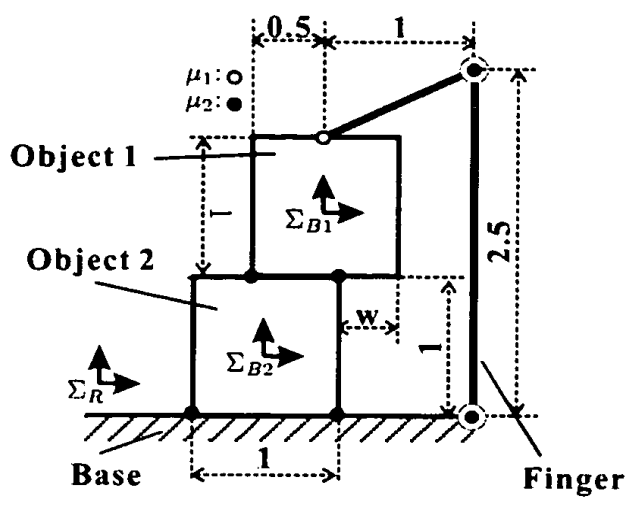

Fig. 2 Examples

$1 \mathcal{T}_{E} \subset \mathcal{W}$

$2 \operatorname{rank} A=6 M+L$ なお, 2 次元平面の場合, 上記の条 件 2 は

$2^{\prime}$ rank $A=3 M+L$

となる.

2.7 数值俉 図 2 に2 次元平面において複数対 象物を把持する場合の例を示す．図中の各対象物は 1 辺の長さが 1 の正方形である. 各接触点での摩擦係数 $\mu_{1}, \mu_{2}$ を $\mu_{1}=\mu_{2}=0.3$ とおく. この例における行列 $\boldsymbol{A}$ は

$A=$
$\left[\begin{array}{cccccccc}1.0 & 0.0 & -0.5 & 0.0 & 0.0 & 0.0 & -2.0 & 0.5 \\ 0.0 & 1.0 & 0.0 & 0.0 & 0.0 & 0.0 & -1.0 & -1.0 \\ 1.0 & 0.0 & 0.5 & -1.0 & 0.0 & 0.5 & 0.0 & 0.0 \\ 0.0 & 1.0 & 0.5-w & 0.0 & -1.0 & -0.5 & 0.0 & 0.0 \\ 1.0 & 0.0 & 0.5 & -1.0 & 0.0 & 0.5 & 0.0 & 0.0 \\ 0.0 & 1.0 & -0.5 & 0.0 & -1.0 & 0.5-w & 0.0 & 0.0 \\ 0.0 & 0.0 & 0.0 & -1.0 & 0.0 & -0.5 & 0.0 & 0.0 \\ 0.0 & 0.0 & 0.0 & 0.0 & -1.0 & -0.5 & 0.0 & 0.0 \\ 0.0 & 0.0 & 0.0 & -1.0 & 0.0 & -0.5 & 0.0 & 0.0 \\ 0.0 & 0.0 & 0.0 & 0.0 & -1.0 & 0.5 & 0.0 & 0.0\end{array}\right]$

, 集合 $\tau_{E}$ は

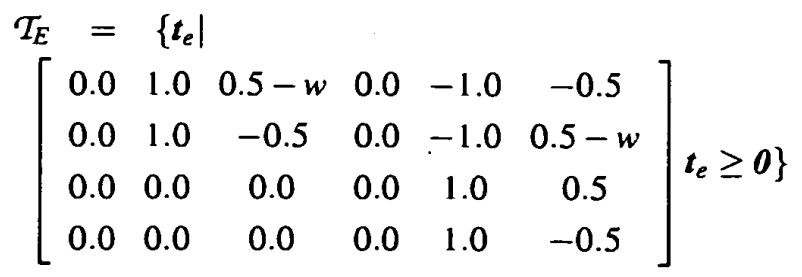

，集合 $\mathcal{W}$ は

$\mathcal{W}=\left\{t_{e} \mid t_{e}=\right.$ 


$$
\begin{aligned}
& -\left[\begin{array}{cc}
-0.40 & 0.40 \\
-0.20 & -0.80 \\
0.20 & -0.20 \\
0.00 & 0.00 \\
0.00 & 0.00 \\
0.00 & 0.00
\end{array}\right] \boldsymbol{\jmath}_{C} k_{C}-\left[\begin{array}{cc}
-0.30 & 0.30 \\
1.00 & 1.00 \\
0.35-w & 0.65-w \\
0.30 & -0.30 \\
-1.00 & -1.00 \\
-0.65 & -0.35
\end{array}\right. \\
& \begin{array}{llllll}
-0.30 & 0.30 & 0.00 & 0.00 & 0.00 & 0.00
\end{array} \\
& \begin{array}{llllll}
1.00 & 1.00 & 0.00 & 0.00 & 0.00 & 0.00
\end{array} \\
& \begin{array}{llllll}
-0.65 & -0.35 & 0.00 & 0.00 & 0.00 & 0.00
\end{array} \\
& \begin{array}{lllllll}
0.30 & -0.30 & 0.30 & -0.30 & 0.30 & -0.30
\end{array} \\
& \begin{array}{llllll}
-1.00 & -1.00 & 1.00 & 1.00 & 1.00 & 1.00
\end{array} \\
& \begin{array}{llllll}
0.35-w & 0.65-w & 0.65 & 0.35 & -0.35 & -0.65
\end{array}
\end{aligned}
$$

$\left.\boldsymbol{k}_{1}^{\prime}, \quad k_{C} \geq 0, \boldsymbol{k}_{1}^{\prime} \geq \boldsymbol{0}\right\}$

となった. ただし，wは図2 2 に示すように对象物 1 と 対象物 2 との右端の辺の位置の差である．また，一定 トルク $\tau_{C}$ の方向 $\hat{\tau}_{C}$ の存在範囲は

$$
\left\{\hat{\boldsymbol{\tau}}_{C} \mid \hat{\boldsymbol{\tau}}_{C}=\left[\begin{array}{cc}
32.0 & 8.0 \\
17.0 & 32.0
\end{array}\right] \boldsymbol{k}_{t c}, \quad \boldsymbol{k}_{t c} \geq \boldsymbol{0}\right\}
$$

となった. $w$ が $0 \leq w<0.8$ であれば, パワーグラス プを実現する一定トルク $\tau_{C}$ が存在するが, $w \geq 0.8$ で あれば, パワーグラスプを実現する一定トルク $\tau_{C}$ は 存在しない.これは複数対象物を把持しているために 生じることであり, 対象物 1 と対象物 2 とがくっつい て単一の対象物となっていれば, $w$ の值に関わらずパ ワーグラスプを実現することができる．なお， $\mathcal{T}_{E} \subset$ $\mathcal{W}$ の判定は, $\mathcal{T}_{E}$ の各稜線べクトルが $\mathcal{W} に$ 含まれる ような一定トルクの方向 $\hat{\tau}_{C}$ が存在するかどうかを線 形計画法を用いて調べた. また, $\operatorname{rankA}$ は $w=1$ の場 合を除いて $8(=3 M+L)$ となった.

\section{3. 最適なパワーグラスプ}

本章では, 最適なパワーグラスプの定義及びその求 め方について述べる.

3.1 最適なパワーグラスプの定義 ある物体を パワーグラスプによって把持するとき，その形態は無 数に存在するため, 何らかの方法でそれらを評洒しな ければならない，そこで本論文では，余ら ${ }^{(7)}$ が定義し ている要求外力集合の考え方を使うことにする．この 要求外力集合に必要な限界外力集合 ${ }^{(6)}$ をまず定義する. 限界外力集合 系がパワーグラスプを構成している際, 把持物体に対して外力 $t_{e}$ が加わるると，関節トルクを 変化させなくても，機構的な内力によってそれとバラ ンスする接触力が発生する. しかしながら，その抵抗 できる外力の大きさには限界が存在する．この限界の
ときの外力を限界外力という。これら全ての限界外力 からなる力集合 $\mathcal{T}_{L} \subset R^{6 M}$ を限界外力集合という.

この限界外力集合をもとに要求外力集合は以下のよ うに定義できる.

要求外力集合 要求外力集合とは，実現しようとする パワーグラスプの限界外力集合がその要求外力集合を 最低限含まなければならない外力の集合 $\mathcal{T}_{R} \subset R^{6 M}$ の ことをいう.

パワーグラスプを用いる目的の一つに，機構的に外 力を打ち消す接触力の発生機能を有効に利用しようと いうことが挙げられる. そこで, 外力に抗するために 加える関節トルクをなるべく小さくすることが外力を 打ち消す接触力を最も有効に利用することになると考 え，以下のように最適なパワーグラスプを定義する.

最適なパワーグラスプ 要求外力集合をその限界外力 集合に含む，すなわち $\mathcal{T}_{R} \subset \mathcal{T}_{L}$ となるパワーグラスプ を構成する一定関節トルク $\tau_{C}$ が以下の評価関数を最 小化するとき，その把持形態を最適なパワーグラスプ と呼ぶ.

$$
\Phi \triangleq \tau_{C}^{T} \tau_{C}
$$

3.2 最適なパワーグラスプの求め方＼cjkstart本節では 前節で定義した最適なパワーグラスプの求め方を示 す.ただし，要求外力集合 $\tau_{R}$ は有界な凸多面体とし て与えられるものとする. また, 各接触点 $C_{j k}$, 各接 触面（線）の端点 $E_{i h l}$ における摩擦円錐を以下のよう に $L_{C_{j k}}, L_{E_{i h l}}$ 面の凸多面錘で近似するものとする ${ }^{(11)}$.

$$
\boldsymbol{V} \boldsymbol{f} \leq \boldsymbol{0}
$$

ただし

$$
\begin{aligned}
& \boldsymbol{V}=\operatorname{diag}\left[\begin{array}{llllll}
\boldsymbol{V}_{C_{11}} & \cdots & \boldsymbol{V}_{C_{N K_{N}}} & \left(\boldsymbol{V}_{E_{011}}\right. & \cdots & \boldsymbol{V}_{E_{0 h T_{0 h}}}
\end{array}\right) \\
& \left.\begin{array}{lll}
\boldsymbol{V}_{E_{121}} & \cdots & V_{E_{M-1 M T_{M-1 M}}}
\end{array}\right] \\
& V_{C_{j k}}=\operatorname{col}\left[\left(a_{k}^{C_{j k}}\right)\right]\left(k=1,2, \cdots, L_{C_{j k}}\right) \\
& V_{E_{i h l}}=\operatorname{col}\left[\left(a_{k}^{E_{i h l}}\right)\right]\left(k=1,2, \cdots, L_{E_{i h l}}\right)
\end{aligned}
$$

であり（col は全ての要素を縦に並べたベクトルまた は行列を表す）， $\boldsymbol{a}_{k}^{C_{j k}}$ は接触点 $C_{j k}$ の凸摩擦多面錘の $k$ 番目の面の外向き法線ベクトルを表している.

まず，要求外力集合 $\mathcal{T}_{R}$ と抗しなければならない外 力集合 $\mathcal{T}_{E}$ の共通集合 $\mathcal{T}_{R} \cap \mathcal{T}_{E}$ を求め，その頂点 $\boldsymbol{t}_{t i}$ $\left(i=1,2, \cdots, \mathrm{T}_{R E}\right)$ を求める ( $\mathrm{T}_{R E}$ は頂点の数). なお, この頂点の求め方は付録に示す. 共通集合 $\mathcal{T}_{R} \cap \mathcal{T}_{E}$ は 有界な凸多面体ゆえ，この頂点に対応する外力全てに 抗することができるなら，共通集合 $\mathcal{T}_{R} \cap \mathcal{T}_{E}$ に含まれ 


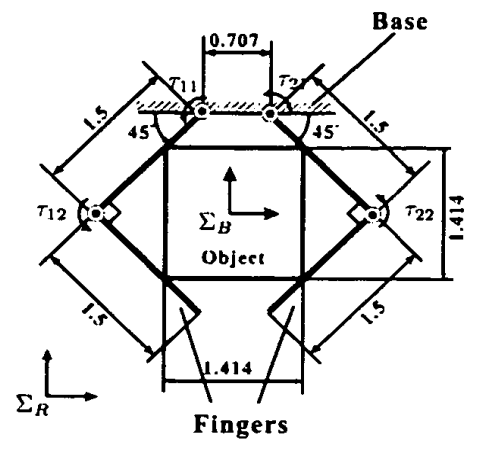

Fig. 3 Robot Hand and One Object

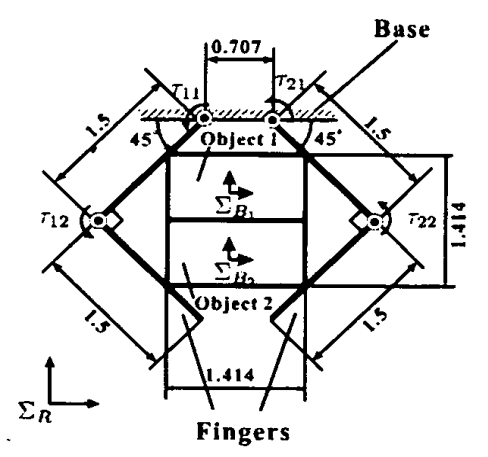

Fig. 4 Robot Hand and Two Objects(I)

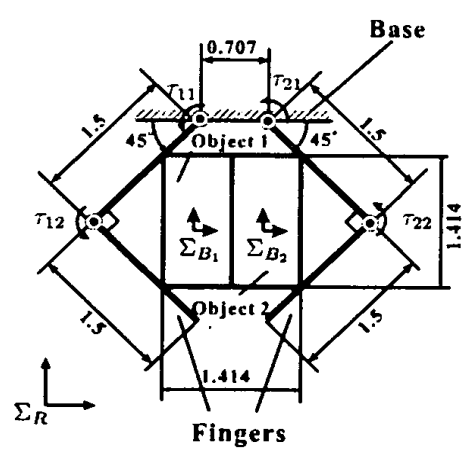

Fig. 5 Robot Hand and Two Objects(II)

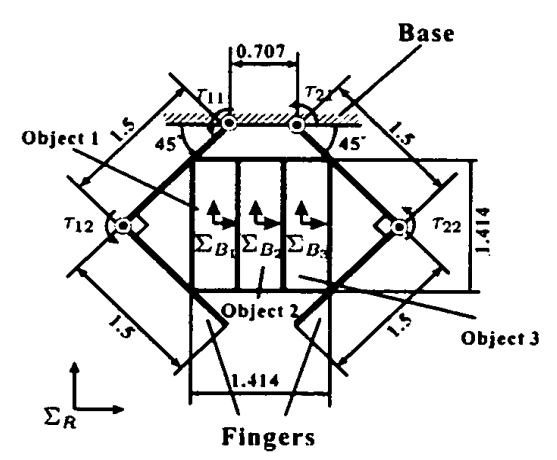

Fig. 6 Robot Hand and Three Objects

る全ての外力に抗することができる.ゆえに，以下の 2 次計画問題を解くことで, 最適なパワーグラスプを

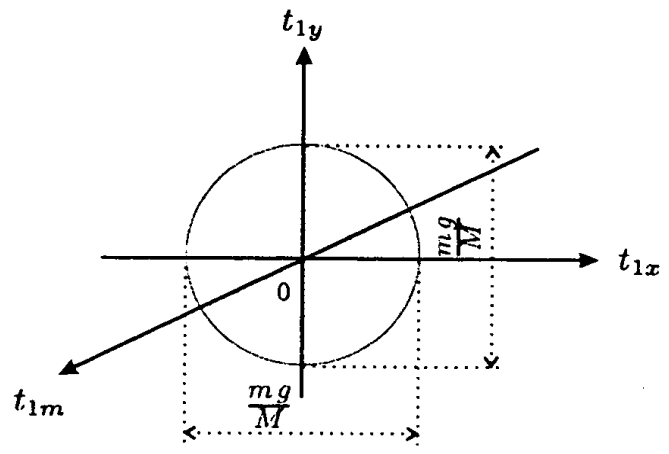

Fig. 7 Required External Force Set for 図 3

Table 1 Joint Torques for Optimal Power Grasp

\begin{tabular}{|c||c|c|}
\hline & $\tau_{11}=-\tau_{21}$ & $\tau_{12}=-\tau_{22}$ \\
\hline \hline one object & 6.000 & 4.486 \\
\hline two objects(I) & 6.447 & 4.912 \\
\hline two objects(II) & 7.640 & 5.599 \\
\hline three objects & 7.838 & 5.767 \\
\hline
\end{tabular}

実現する一定トルク $\tau_{C}$ が求められる.

$$
\min \Phi=\tau_{C}^{T} \tau_{C}
$$

$$
\begin{array}{r}
\text { subject to. } \quad \boldsymbol{V}\left\{\left(\boldsymbol{A}^{T}\right)^{+}\left[\begin{array}{c}
-\boldsymbol{t}_{t i} \\
\boldsymbol{\tau}_{C}
\end{array}\right]+\boldsymbol{H} \boldsymbol{k}_{t i}\right\} \leq \mathbf{0} \\
\left(i=1,2, \cdots, \mathrm{T}_{R E}\right)
\end{array}
$$

ただし, $\boldsymbol{H} \in \mathcal{R}^{3(K+T) \times(3(K+T)-6 M-L)}$ は $\boldsymbol{A}^{T} \boldsymbol{H}=\boldsymbol{0}$ を満 たす任意の行列で rank が $3(K+T)-6 M-L$ であり, $\boldsymbol{k}_{t i}\left(i=1,2, \cdots, \mathrm{T}_{R E}\right)$ は $\boldsymbol{H}$ の列方向の接触力の大きさを 表すパラメータベクトルである.

\section{4. 数 值 例}

本章では，図3～図 6に示すような，ロボットハン ドによって単一または複数の凸多角形対象物を平面把 持するときの最適なパワーグラスプを, 前章の方法を 用いて求める. なお, 簡単のため以下のような仮定を 設ける. 図3～図6に示す各対象物は均一かつ同一の 密度を持つ. 各対象物に固定されている座標系 $\Sigma_{B i}$ は 各対象物の重心位置に固定されているものとする，ロ ボットハンドと対象物の間の最大静止摩擦係数及び対 象物間の最大静止摩擦係数はすべて等しく 0.3 である.

各系に対する要求外力集合は, 各対象物にはたらく 外力 $t_{i}$ のうち $x, y$ 方向の並進成分をそれぞれ $t_{i x}, t_{i y}$, 回転モーメント成分を $t_{i m}$ と置いて，以下のように与 えるものとする.

$$
\begin{aligned}
\mathcal{T}_{R}=\left\{t_{i x}=t_{x}, t_{i y}=t_{y}, t_{i m}\right. & =0 \mid \\
\sqrt{t_{x}^{2}+t_{y}^{2}} & \left.\leq \frac{m g}{M}\right\}
\end{aligned}
$$


ただし, $m$ は $M$ 個の対象物の重量の合計, $g$ は重力 加速度を表している. 例として, 図 3 に示す系に対す る要求外力集合を図 7 に示す. この要求外力集合は, 各系が同じ重力場に置かれ, その中でハンドがいかな る姿勢をとってもパワーグラスプを維持できることを 要求したことに相当する. なお, 実際の数値計算にお いては, $m g=1.5$ とおき, 図 7 に示すような 2 次元 円を 2 次元正 64 面形に近似して計算した. また, ど の系においても， $\mathcal{T}_{R} \subset \mathcal{T}_{E}$ が成り立ったため, 共通集 合 $\mathcal{T}_{R} \cap \mathcal{T}_{E}$ の頂点は $\mathcal{T}_{R}$ の頂点と一致するとして計算 した.

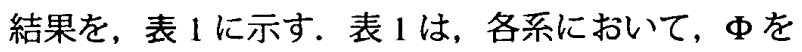
最小とする最適なパワーグラスプを構成する場合の関 節トルクの值を表している. 表 1 から, パワーグラス プを実現するために必要な関節トルクの大きさは，対 象物の数が多くなるほど大きくなっていることがわか る. また，2つの対象物を同時に把持する場合, 最適 なパワーグラスプを実現するために必要な関節トルク の大きさは，上下に配置する方が左右に配置する方よ りも小さくなることがわかる.

\section{5.おわりに}

本論文では, 多自由度を持つ複数本の指で複数対象 物を包み込み把握する場合についてパワーグラスプが 成り立つ条件を考察した. また, パワーグラスプの機 能を最も有効に利用するものを最適なパワーグラスプ と定義し，その求め方について考察し，数值例によっ て最適なパワーグラスプを求めた.

単一対象物のパワーグラスプとの違いでは，以下の 点を明らかにした。

1. 対象物間の拘束のみによって抗することができる 外力が存在することを考察し，それは対象物間の 接触面（線）の法線方向において互いに同じ大き さの力で押しつけ合う力であることを示した. ま た，これに対応する外力を含まない全ての外力に 抗することができれば，各対象物にはたらく任意 の方向の外力に抗することができることを示した.

2. 数值例において, 複数対象物を把持している場合 パワーグラスプを構成できなくとも，それら複数 対象物を互いにくっつけて単一の対象物と見なせ ば, パワーグラスプを構成できる場合が存在する ことを示した．また，複数の対象物を把持する場 合, パワーグラスプを構成するのに必要な関節卜 ルクの大きさは, 対象物の数が多ければ多いほど 大きくなることを示した.
文献

(1) Y. Aiyama, M. Minami, and T. Arai, Pro. of IEEE int. Conf. on Robotics and Automation, (1998), 2904-2909

(2) 余・福田・辻尾, 日本機械学会, ロボティクス・メカト ロニクス講演会論文集, (1998), 1 A 1-50-078

(3) 原田・金子日本ロボット学会, 16-6, (1998), 860-867

(4) 原田・金子, 17-1, (1999), 133-139

(5) 小俣・永田, 日本ロボット学会, 13-4, (1995), 525-531

(6) 中村·張・吉本, 日本ロボット学会, 13-6, (1995), 866-874

(7) 余・竹内・吉川, 日本ロボット学会, 17-4, (1999), 557-66

(8) 吉川、日本ロボット学会, 14-4, (1996), 505-511

(9) 平井・浅田・得丸, 計測自動制御学会論文集, 24-12, (1988), 1284-1291

(10) 布川・中山・谷野, コロナ社, (1991)

(11) J. Kerr and B. Roth, International Journal of Robotics Research, 4-4, (1986), 3-17

\section{A. 共通集合 $\mathcal{T}_{R} \cap \mathcal{T}_{E}$ の頂点}

今, 要求外力集合 $\mathcal{T}_{R}$ を

$$
\mathcal{T}_{R}=\left\{\boldsymbol{t}_{e} \mid \boldsymbol{S t _ { e }} \leq \boldsymbol{s}\right\}
$$

とおく. すると, 式(15) より, 共通集合 $\mathcal{T}_{R} \cap \mathcal{T}_{E}$ は

$$
\begin{aligned}
\mathcal{T}_{R} & =\left\{\boldsymbol{t}_{e} \mid\left(\begin{array}{c}
\boldsymbol{N}_{E}^{T} \boldsymbol{D}_{E} \\
\boldsymbol{W}
\end{array}\right) \boldsymbol{t}_{e} \leq\left(\begin{array}{l}
\boldsymbol{0} \\
\boldsymbol{s}
\end{array}\right)\right\} \\
& \triangleq\left\{\boldsymbol{t}_{e} \mid \boldsymbol{Z} \boldsymbol{t}_{e} \leq \boldsymbol{z}\right\}
\end{aligned}
$$

と表すことができる．この集合の不等式の $Z$ の 行 $\left(Z_{1}, Z_{2}, \cdots\right)$ のうち, $6 M$ 個の 1 次独立な行 $\left(Z_{r 1}, \cdots, Z_{r 6 M}\right)$ を選び, これに対応する不等式 $\left(Z_{r \mid} t_{e}\right.$ $\left.\leq z_{r 1}, \cdots, Z_{r a M} t_{e} \leq z_{r \sigma M}\right)$ を式(28) より抽出して不等式

$$
\left[\begin{array}{c}
Z_{r 1} \\
\vdots \\
Z_{r 6 M}
\end{array}\right] t_{e} \leq\left[\begin{array}{c}
z_{r 1} \\
\vdots \\
z_{r 6 M}
\end{array}\right]
$$

を構成する. このとき共通集合 $\mathcal{T}_{R} \cap \mathcal{T}_{E}$ の頂点の候補 と成り得る候補頂点は，

$$
t_{e}=\left[\begin{array}{c}
Z_{r 1} \\
\vdots \\
Z_{r 6 M}
\end{array}\right]^{-1}\left[\begin{array}{c}
z_{r 1} \\
\vdots \\
z_{r G M}
\end{array}\right]
$$

で得られる.この方法を用いて候補頂点を全探索的に 求める. 求められた候補頂点のうち, 式(28)を満たす 頂点が共通集合 $\mathcal{T}_{R} \cap \mathcal{T}_{E}$ の頂点である. 